\title{
Augmented Reality Book Pengenalan Perangkat Gamelan Bali
}

\author{
I Kadek Yostab Mariyantoni ${ }^{1}$, Padma Nyoman Crisnapati ${ }^{2}$, \\ I Gede Mahendra Darmawiguna ${ }^{3}$, Made Windu Antara Kesiman ${ }^{4}$ \\ Jurusan Pendidikan Teknik Informatika \\ Universitas Pendidikan Ganesha \\ Singaraja, Bali \\ E-mail: yostab.mariyantoni@gmail.com ${ }^{1}$ crisnapati@yahoo.com ${ }^{2}$,igd.mahendra.d@gmail.com ${ }^{3}$, \\ dekndu@yahoo.com ${ }^{4}$
}

\begin{abstract}
Abstrak-Gamelan Bali semakin ditinggalkan oleh remaja, salah satu faktor penyebabnya adalah perkembangan teknologi. Tujuan dari penelitian ini adalah untuk memanfaatkan teknologi dengan cara mengembangkan aplikasi yang dapat digunakan sebagai media untuk mempelajari dan memperkenalkan perangkat gamelan Bali dengan lebih interaktif dan menarik. Metode penelitian yang digunakan adalah penelitian dan pengembangan, untuk mengembangkan aplikasi Augmented RealityBookpengenalan perangkat gamelan Bali, dengan menggunakan model waterfall sampai pada tahap pengujian sistem. Aplikasi ini menggunakan library vuforia yang mampu memainkan suara dan menampilkan objek 3 dimensi perangkat gamelan Bali ke dalam sebuah lingkungan nyata dengan menggunakan bantuan buku dan smartphone android.Hasil akhirnya berupa buku yang berisikan informasi dan gambar terkait gamelan Bali (khusus gong kebyar) yang difungsikan sebagai penanda dan juga aplikasi Augmented Reality Bookberbasis android yang mampu menampilkan objek perangkat gamelangong kebyar dalam bentuk 3 dimensi tepat di atas marker lengkap dengan suara dari perangkat gamelan dan suara narasi penjelasan. Aplikasi ini dapat dijadikan sebagai media untuk memperkenalkan sekaligus melestarikan budaya bangsa.
\end{abstract}

Kata kunci : Gamelan

Bali,Augmented RealityBook,libraryVuforia, Android, Gong Kebyar.

Abstract-Balinese gamelan are being abandoned by teenagers, one of contributing factor is the development of technology. The destination of this research is to utilize technology in a way to develop applications that can be used as a media for learning and introduce Balinese gamelan instruments with a more interactive and interesting. The research method used is the research and development, to develop an Augmented Reality Book application for introduction the Balinese gamelan instrument, using the waterfall model until the system testing phase. This application uses library vuforia that can be play a sound and display $3 D$ objects Balinese gamelan instruments in a real environment with the help of books and android smartphones. The final result is a book that contains information and images related to Balinese gamelan (specially gong kebyar) which functioned as a marker and also Augmented Reality Book application android based device that is capable of displaying objects gamelan gong kebyar in 3-dimensional form just above the marker complete with the sound of the device gamelan and voice narration explanation. This application can be used as a media to introduce and preserve the national culture.

Keywords- Balinese gamelan,Augmented RealityBook,library Vuforia, Android,Gong Kebyar

\section{PENDAHULUAN}

Minat masyarakat asing akan kesenian gamelan Bali cukup tinggi. Kementerian Pendidikan dan Kebudayaan (Kemendikbud) memberikan kepercayaan kepada ISI Denpasar untuk mendidik mahasiswa asing yang berasal dari 34 negara dari berbagai belahan dunia untuk mendalami tabuh dan tari Bali. Selama kurun waktu 12 tahun periode 1999-2011, sudah 382 orang mahasiswa asing belajar tabuh dan tari Bali di ISI Denpasar. Hasil penelitian yang dilakukan di sejumlah negara, masyarakat setempat sangat menikmati konser gamelan Bali yang disajikan seniman dan mahasiswa yang piawai memainkan aneka jenis alat musik Bali [1].Sayangnya, keinginan untuk mengenal gamelan Bali lebih jauh terbentur masalah sulitnya mencari perangkat gamelan tersebut secara nyata, begitu pula dengan referensi mengenai gamelan Bali yang masih minim.

Pada era globalisasi seperti sekarang ini, kebanyakan remaja khusunya di Bali sudah cenderung lemah tingkat kepeduliannya terhadap kebudayaan yang dimiliki khusunya seni tabuh dan tari. Mereka lebih memilih mempelajari tarian modern (Modern Dance) dan musik modern 
daripada musik gamelan tradisional, bahkan bergaya hidup ke barat-baratan[2].

Di sisi lain teknologi juga menjadi salah satu faktor yang mejadikan rendahnya minat masyarakat khususnya remaja untuk turut melestarikan budaya yang ada. Hal ini harus ditekankan bahwa jangan sampai kemajuan teknologi menyebabkan para remaja atau anak muda kehilangan jati diri mereka, melainkan memanfaatkan teknologi untuk turut serta melestarikan kebudayaan bangsa.

Pelestarian kebudayaan bangsa dapat pula diupayakan dengan bantuan teknologi. Teknologi perkembangannya cukup pesat saat ini adalah teknologi augmented reality yang menggabungkan benda maya 3 dimensi ke lingkungan nyata. Dengan membuat dan menampilkan objek berupa 3D dari perangkat gamelan Bali tersebut ditambah dengan menampilkan suara yang dapat dihasilkan dari alat gamelan tersebut dapat mempermudah seseorang baik itu masyarakat asing maupun masyarakat lokal untuk dapat mengenal dan mempelajari gamelan Bali ini dengan lebih interaktif dan menarik. Remaja akan cenderung lebih tertarik dengan apa yang ditampilkan melalui teknologi augmented reality tersebut karena lebih menarik dibandingkan dengan mempelajari dari buku-buku kebudayaan yang ada.

\section{II.KAJIAN TEORI}

\section{A. Augmented Reality}

Secara umum, Augmented Reality (AR) adalah suatu teknologi yang menggabungkan benda maya dua dimensi dan ataupun tiga dimensi ke dalam sebuah lingkungan nyata tiga dimensi lalu memproyeksikan benda-benda maya tersebut dalam waktu nyata. Ronald T. Azuma (1997) mendefinisikan Augmented Reality sebagai penggabungan benda-benda nyata dan maya di lingkungan nyata, berjalan secara interaktif dalam waktu nyata, dan terdapat integrasi antarbenda dalam tiga dimensi, yaitu benda maya terintegrasi dalam dunia nyata. Penggabungan benda nyata dan maya dimungkinkan dengan teknologi tampilan yang sesuai, interaktivitas dimungkinkan melalui perangkat-perangkat input tertentu, dan integrasi yang baik memerlukan penjejakan yang efektifโ37. Selain menambahkan benda maya dalam lingkungan nyata, realitas tertambah juga berpotensi menghilangkan benda-benda yang sudah ada. Menambah sebuah lapisan gambar maya dimungkinkan untuk menghilangkan atau menyembunyikan lingkungan nyata dari pandangan pengguna.

\section{B. Vuforia}

Vuforia merupakansoftwarelibrary untuk augmented reality, yang menggunakan sumber yang konsisten mengenai computer vision yang fokus pada image recognition. Vuforia mempunyai banyak fitur-fitur dan kemampuan, yang dapat membantu pengembang untuk mewujudkan pemikiran mereka tanpa adanya batas secara teknikal. Dengan support untuk iOS, Android, dan Unity3D, platform Vuforia mendukung para pengembang untuk membuat aplikasi yang dapat digunakan di hampir seluruh jenis smartphone dan tablet. Pengembang juga diberikan kebebasan untuk mendesain dan membuat aplikasi yang mempunyai kemampuan antara lain :

1. Teknologi computer vision tingkat tinggi

2. Terus-menerus mengenali multiple image.

3. Tracking dan Detection tingkat lanjut.

4. Dan solusi pengaturan database gambar yang fleksibel.

\section{Unity $3 D$}

Unity 3D merupakan sebuah tools yang terintegrasi untuk membuat bentuk obyek 3 dimensi pada video games atau untuk konteks interaktif lain seperti Visualisasi Arsitektur atau animasi 3D real-time. Lingkungan dari pengembangan Unity 3D berjalan pada Microsoft Windows dan Mac Os X, serta aplikasi yang dibuat oleh Unity 3D dapat berjalan pada Windows, Mac, Xbox 360, Playstation 3, Wii, iPad, iPhone dan tidak ketinggalan pada platform Android. Unity juga dapat membuat game berbasis browser yang menggunakan Unity web player plugin, yang dapat bekerja pada Mac dan Windows, tapi tidak pada Linux.

\section{Augmented Reality Book}

Augmented Reality Book (AR-Book) merupakan penggabungan antara buku biasa dengan teknologi AR. AR-Book secara garis besar memiliki dua komponen utama, yaitu buku yang dilengkapi dengan marker berjenis Quick Response Code (QRC) pada hampir setiap halamannya, dan yang kedua yaitu peralatan untuk menangkap marker dan menampilkan hasilnya. Augmented Reality Book termasuk dalam kategori sumber belajar yang didesain khusus, karena dikembangkan sebagai komponen dalam hal mempermudah pengguna memahami isi buku dengan cara menampilkan objek berupa 3 dimensi pada gambar 2 dimensi yang tertera pada buku. Augmented Reality Book juga dapat dikatakan sebagai media karena berbentuk bahan cetakan 
yang dapat menampilkan informasi yang diperlukan.

\section{E. Gamelan Bali}

Salah satu contoh gamelan bali yaitu gong kebyar. Gong Kebyar adalah sebuah barungan (perangkat gamelan) yang tergolong baru. Sesuai dengan nama yang diberikan kepada barungan ini (Kebyar yang bermakna cepat, tiba-tiba dan keras) gamelan ini menghasilkan musik-musik keras dan dinamis.[4].

Perangkat gamelan gong kebyar terdiri dari 2 buah ugal, 4 buah pemade, 4 buah kantilan, 2 buah penyacah, 2 buah jublag, 2 buah jegogan, 1 buah rebab, 1 buah trompong, 1 buah riyong, 2 buah kendang, 2 jenis cengceng, 1 buah kajar, 2 buah gong, 1 buah kempli, 1 buah kempur, 1 buah bebende, 1-3 buah suling, dan 1 buah kemong[5].

\section{METODOLOGI}

\section{A. Analisis Perangkat Lunak}

Pada tahap kedua yaitu analisis perangkat lunak yang pada model waterfall masuk kedalam bagian dari System and software design (sistem dan desain perangkat lunak).

1) Kebutuhan Perangkat Lunak

Perangkat lunak yang akan dibangun adalah aplikasi menggunakan teknologi Augmented Realityberbasis android dengan menggunakan buku sebagai media pendukung penggunaan aplikasi ini. Buku dengan teknologi AR ini secara garis besar berisikan tentang gambar dari tiap perangkat gamelan gong kebyar yang difungsikan sebagai penanda(marker) dan penjelasan mengenai perangkat gamelan Bali tersebut. Marker akan menampilkan objek 3 dimensi yang telah dibuat sesuai dengan isi buku. Buku berbasis AR ini menjelaskan tentang gamelan Bali khususnya Gong Kebyar.

2) Tujuan Pengembangan Perangkat Lunak

Tujuan dari pengembangan perangkat lunak ini adalah mengembangkan sebuah perangkat lunak yang digunakan untuk menampilkan objek 3 dimensi berupa perangkat gamelan Gong Kebyar, tepat diatas gambar penanda ketika diarahkan oleh kamera smartphone.

3) Masukan dan Keluaran Perangkat Lunak

1. Masukan: marker atau penanda yang ditampilkan pada buku dan gambar. Hasil tangkapan kamera mencari marker berupa frame yang akan di identifikasi oleh aplikasi.

2. Keluaran: objek 3 dimensi gamelan Gong Kebyar yang dihasilkan dari hasil pencocokan marker dan contoh suara yang dapat dihasilkan dari perangkat gamelan Gong kebyar tersebut.

4) Model Fungsional Perangkat Lunak

Berdasarkan analisis sistem yang telah dilakukan maka digunakanlah flowchart untuk mendeskripsikan alur proses aplikasi yang menggambarkan hubungan antara pengguna dengan perangkat lunak, seperti telihat pada Gambar 2.

Begitu pula dengan proses interaksi yang terjadi antara aplikasi dengan user terlihat pada Gambar 1.

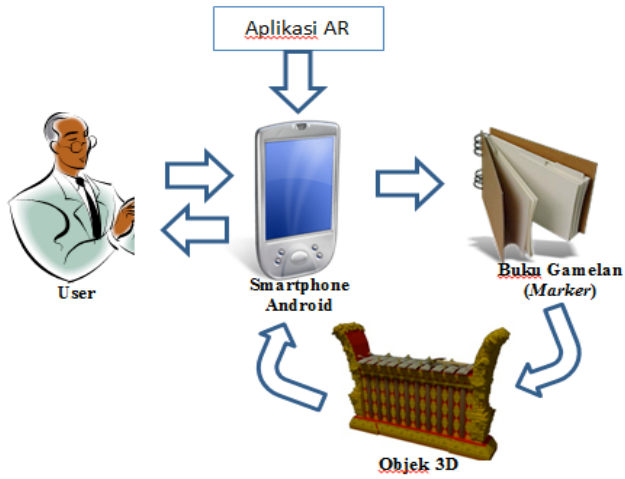

Gambar 1. Blok Diagram Proses interaksi aplikas dengan user

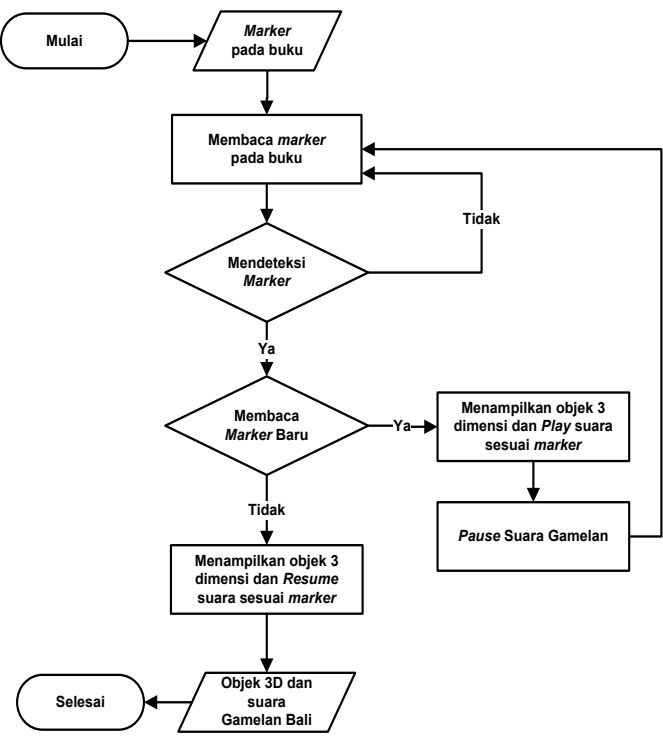

Gambar 2. Flowchart Aplikasi Augmented Reality Book Pengenalan Perangkat Gamelan Bali 


\section{B. Perancangan Perangkat Lunak}

Tahap perancangan perangkat lunak adalah tahap selanjutnya setelah melakukan analisis perangkat lunak. Rancangan perangkat lunak yang dibuat bersifat user friendly agar pengguna merasa nyaman dan mudah untuk menggunakannya.

1) Batasan Perancangan Perangkat Lunak

Adapun batasan yang terdapat dalam implementasi perangkat lunak Augmented Reality Book pengenalan perangkat gamelan Bali yaitu aplikasi ini hanya dapat berjalan pada perangkat android versi 2.2 (Froyo) keatas, dengan OpenGL ES diatas 2.0, dan arsitektur ARMv7.

2) Perancangan Arsitektur Perangkat Lunak

Perancangan arsitektur perangkat lunak menggambarkan bagian-bagian modul, struktur ketergantungan antar modul, dan hubungan antar modul dari perangkat lunak yang dibangun seperti yang terlihat pada Gambar 3.

Begitu pula Use Case Diagram menggambarkan kebutuhan sistem dari sudut pandang user dan memfokuskan pada proses komputerisasi seperti terlihat pada Gambar 4.

Berdasarkan Use Case Diagramtersebut, maka dapat ditentukan activity diagram dari aplikasi Augmented Reality BookPengenalan Perangkat Gamelan Bali seperti terlihat pada Gambar 5.

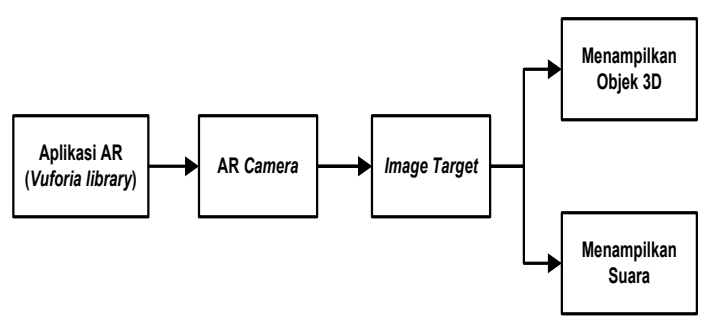

Gambar 3.Structure Chart Perangkat Lunak

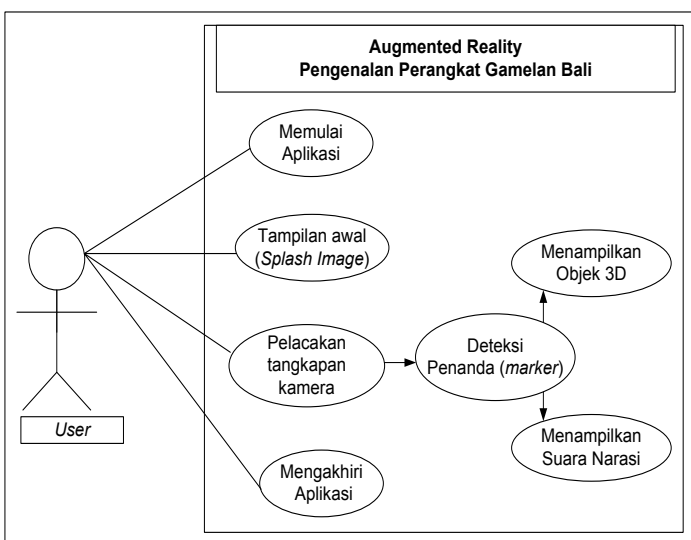

Gambar 4. Use Case DiagramPerangkat Lunak

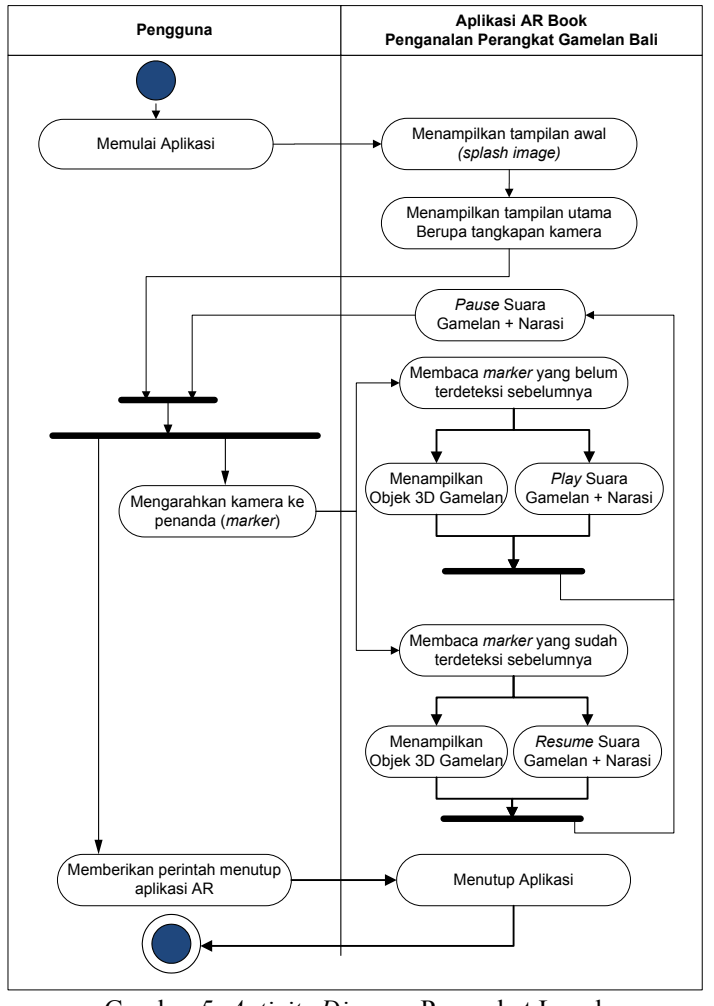

Gambar 5. Activity DiagramPerangkat Lunak

\section{PEMBAHASAN}

\section{A. Implementasi Perangkat Lunak}

Pada tahap implementasi perangkat lunak akan dipaparkan beberapa hal yang berkaitan dengan implementasi perangkat lunak, yaitu lingkungan implementasi perangkat lunak, batasan implementasi perangkat lunak, implementasi struktur data perangkat lunak serta implementasi layar antarmuka perangkat lunak. 
1) Lingkungan Implementasi Perangkat Lunak Pada lingkungan perangkat lunak, aplikasi dijalankan pada Sistem Operasi Windows 7,Sistem Operasi Android Jelly Bean v4.2.2, Blender 2.66, Vuforia Qualcomm Augmented Reality, Unity 4.0.1f2, SDK Android Tools, Audacity.

Pada lingkungan perangkat keras, aplikasi dijalankan pada Laptop Toshiba Satellite L745, Intel ${ }^{\circledR}$ Core $^{\mathrm{TM}}$ i5-2410 CPU (a) 2.30GHz, RAM 6.00 GB, Harddisk 500 $\mathrm{GB}$, dan dilengkapi dengan alat inpun dan output.

Dan pada perangkat android dengan spesifikasi Smartphone LG Nexus 4, Resolusi 768 x 1280 pixels, 4.7 inches, Processor Snapdragon Quad-core 1.5 GHz, RAM 2 GB dan Camera 8MP.

2) Batasan Implementasi Perangkat Lunak

Batasan yang terdapat dalam implementasi perangkat lunak aplikasi Augmented Reality Book pengenalan perangkat gamelan Bali yaitu aplikasi ini hanya dapat berjalan pada perangkat android versi 2.2 (Froyo) keatas, dengan OpenGL ES diatas 2.0, dan arsitektur ARMv7.

Aplikasi ini juga harus dibagi menjadi 2 file aplikasi berformat ".apk" karena perangkat android tidak dapat menampilkan keseluruhan dari objek 3D gamelan dalam satu aplikasi.

3) Implementasi Arsitektur Perangkat Lunak Implementasi proses perangkat lunak Augmented Reality Book pengenalan perangkat gamelan Bali, yakni QCARBehaviour.cs, BackCatcher.cs, DataSetLoadBehaviour.cs,

DefaultTrackableEventHandler.cs dan ImageTargetBehaviour.cs. Penerapan pada perangkat lunak Unity menggunakanclass class yang disimpan dalam format file ".cs".

4) Implementasi Penanda (Marker) Perangkat Lunak

Berdasarkan perancangan model fungsional yang telah dibuat, diperlukan penanda (marker) yang akan dilacak oleh kamera smartphone pada teknologi Augmented Reality. Perangkat lunak Augmented Reality Book pengenalan perangkat gamelan Bali menggunakan 20 gambar (marker) yang dapat dilihat pada gambar 6 .

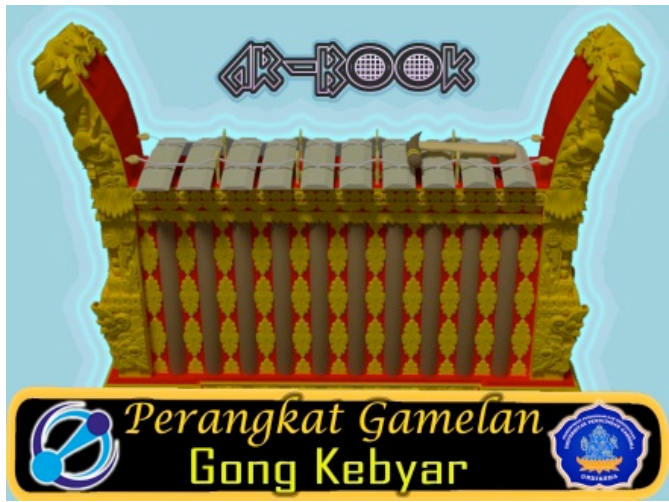

Gambar 6a. Implementasi Penanda Sampul Buku

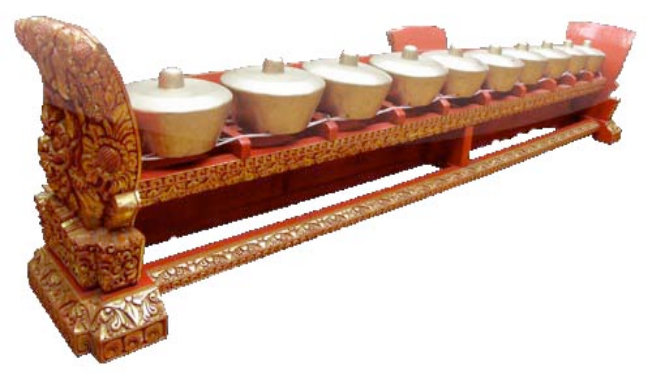

Gambar 6b. Implementasi Penanda Trompong

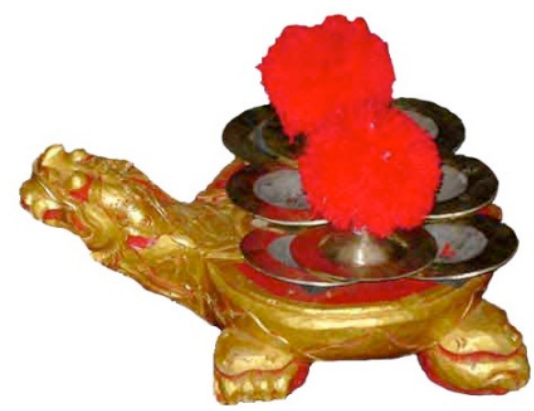

Gambar 6c. Implementasi Penanda Ceng-ceng kecek

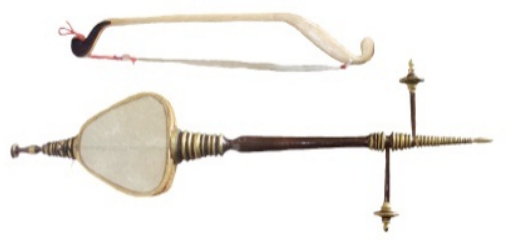

Gambar 6d. Implementasi Penanda Rebab 


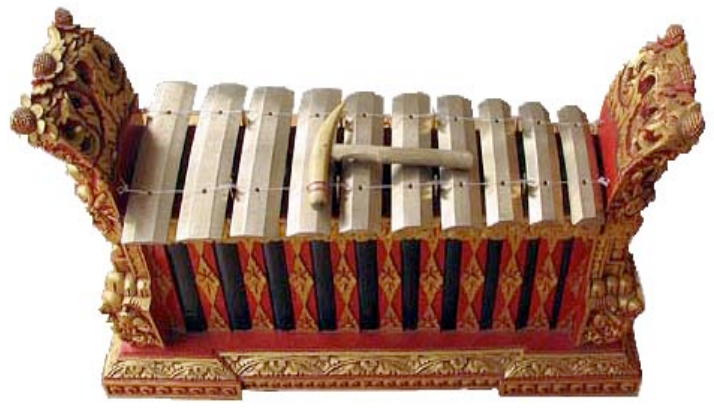

Gambar 6e. Implementasi Penanda Ugal

5) Implementasi Layar Antarmuka Perangkat Lunak

Implementasi tampilan layar antarmuka perangkat lunak Augmented Reality Book pengenalan perangkat gamelan Bali menggunakan fitur-fitur yang terdapat pada Unity 3D dan ditambah dengan library vuforia untuk mendukung pembuatan aplikasi augmented reality.

Implementasi layar antarmuka aplikasi Augmented Reality Book pengenalan perangkat gamelan Bali dapat dilihat pada Gambar 7.

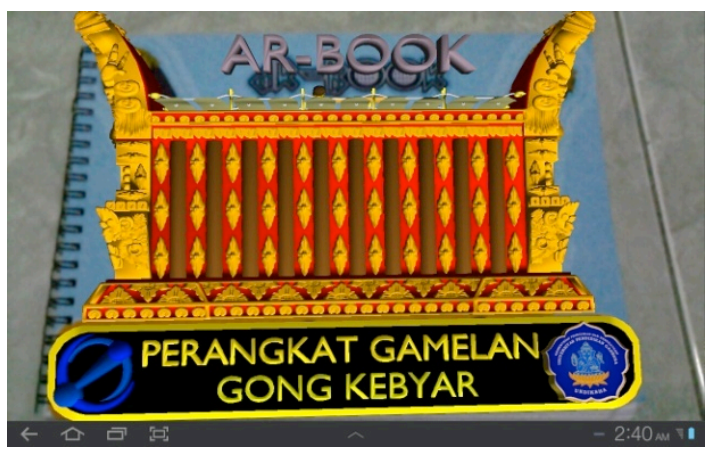

Gambar 7a. Implementasi Layar Utama Aplikasi menampilkan objek sampul

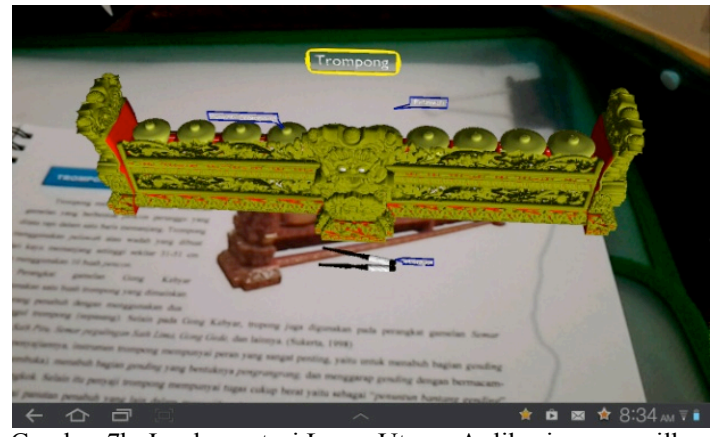

Gambar 7b. Implementasi Layar Utama Aplikasi menampilkan objek trompong

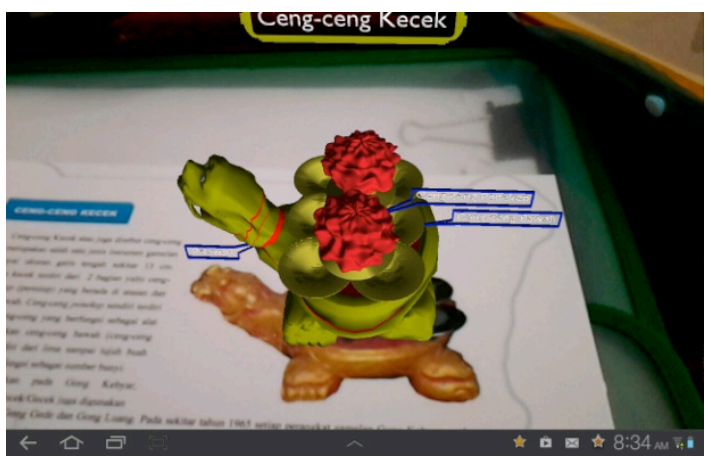

Gambar 7c. Implementasi Layar Utama Aplikasi menampilkan objek ceng-ceng kecek

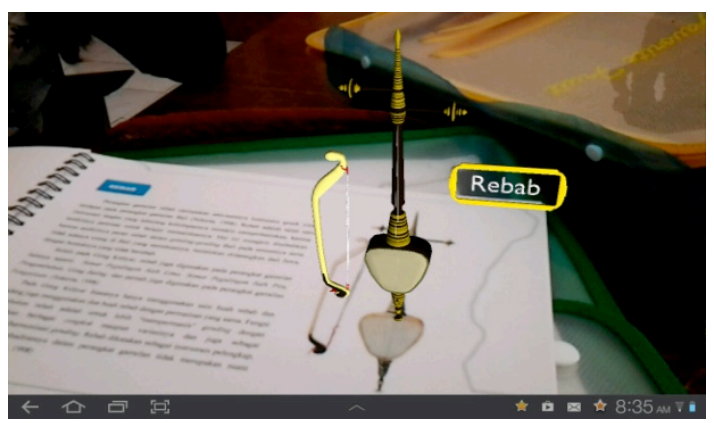

Gambar 7d. Implementasi Layar Utama Aplikasi menampilkan objek rebab

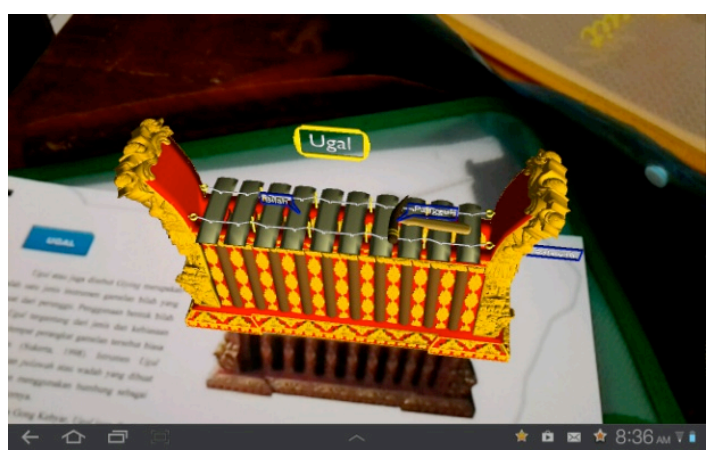

Gambar 7e. Implementasi Layar Utama Aplikasi menampilkan objek ugal

Adapun fitur yang terdapat pada aplikasi Augmented Reality Book pengenalan perangkat gamelan Bali adalah mampu menampilkan objek 3 dimensi beraupa perangkat gamelan Bali khususnya Gong Kebyar. Selain itu aplikasi ini juga mampu memainkan suara berupa narasi penjelasan terkait objek gamelan Bali yang ditampilkan, dan kemudian akan dilanjutkan dengan memainkan suara yang dapat dihasilkan dari perangkat gamelan Bali tersebut.

\section{B. Pengujian Perangkat Lunak}

Tahap selanjutnya setelah implementasi perangkat lunak adalah tahap pengujian perangkat 
lunak. Pada tahap pengujian ini akan dipaparkan mengenai tujuan pengujian perangkat lunak, pelaksanaan pengujian perangkat lunak serta evaluasi dari pengujian perangkat lunak.

1) Tujuan Pengujian Perangkat Lunak

Pengujian perangkat lunak aplikasi Augmented Reality Book pengenalan perangkat gamelan Bali dilakukan dengan mempergunakan pengujian blackbox testing. Dimana pengujian ini hanya dilihat berdasarkan keluaran yang dihasilkan dari data atau kondisi masukan yang diberikan untuk fungsi yang terdapat pada perangkat lunak tanpa melihat bagaimana proses untuk mendapatkan keluaran.

Tujuan pengujian aplikasi adalah:

- Menguji kebenaran proses aplikasi sesuai dengan buku AR-Book.

- Mengujilama waktu menampilkan (render) objek 3D pada aplikasi.

- Menguji penggunaan aplikasi pada tiga orang dengan menggunakan smartphone androidyang berbeda.

2) Pelaksanaan Pengujian Perangkat Lunak

Berdasarkan perancangan pengujian perangkat lunak di atas, maka pengujian aplikasi Augmented Reality Book pengenalan perangkat gamelan Bali dilakukan oleh: 1) Pengembang untuk pengujian kesesuai proses aplikasi; 2) beberapa orang mahasiswa dari jurusan Pendidikan Teknik Informatika, Universitas Pendidikan Ganesha Singaraja. Pengujian dilakukan sesuai dengan kasus uji yang telah dirancang sebelumnya dengan menggunakan tiga jenis angket yaitu:

- Angket kesesuaianjalannya proses aplikasi dengan gambar pada buku

- Angket lama waktu menampilkan objek 3D di luar ruangan dan di dalam ruangan

- Angket penggunaan aplikasi pada jenis hardware berdeda.

3) Evaluasi Hasil Pengujian Perangkat Lunak

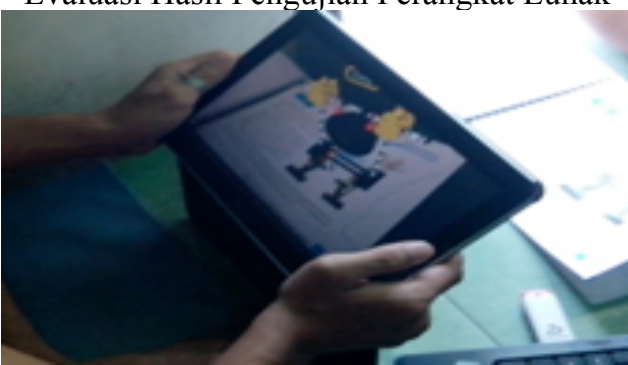

Gambar 8.Pengujian kesesuaian jalannya proses aplikasi dengan gambar pada buku

Melalui hasil pengujian angket kesesuaian jalannya proses aplikasi dengan gambar pada bukudiketahui bahwa proses aplikasi telah sesuai dengan buku $A R$-BookPerangkat Gong Kebyar. Semua prosesaplikasi berfungsi dengan baik.Suara dan objek 3 dimensi yang ditampilkan sesuai dengan gambar pada buku.

Pada pengujian melalui angket lama waktu menampilkan (render) objek 3D pada siang dan malam hari, kedua kondisi memiliki waktu tercepat menampilkan (render) objek 3 dimensi yaitu saat smartphone ke penanda (marker) berjarak $30 \mathrm{~cm}$. Hal ini disebabkan karena ketika berjarak $10 \mathrm{~cm}$ dan $20 \mathrm{~cm}$ masih ada gambar penanda yang sulit terdeteksi keseluruhan, sehingga ketika berjarak $30 \mathrm{~cm}$ keseluruhan dari gambar penanda dapat terdeteksi dengan baik, hanya saja terdapat faktor dari penanda yang kurang baik sehingga aplikasi membutuhkan waktu untuk melakukan render objek yaitu pada objek suling dan rebab. Dari kedua kondisi uji tersebut waktu terlama adalah ketika menampilkan objek suling karena selain dipengaruhi oleh jarak, marker yang digunakan juga memiliki kualitas warna yang tidak kompleks sehingga lebih sulit terdeteksi.

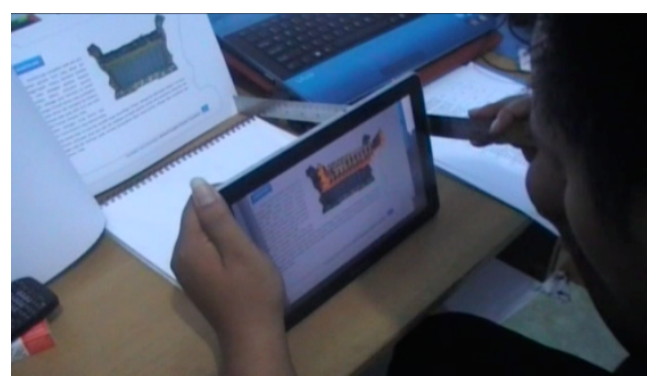

Gambar 9.Pengujian lama waktu menampilkan objek

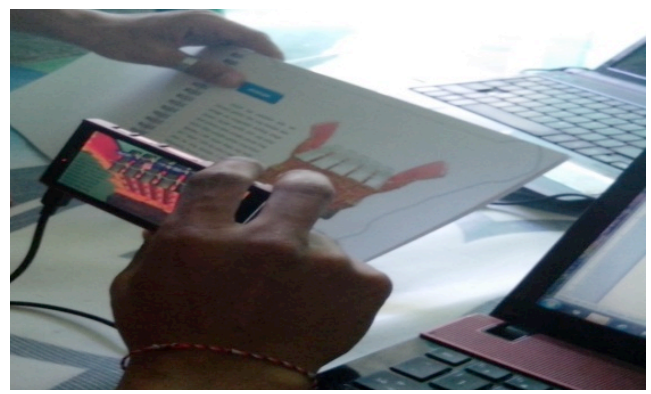

Gambar 10. Pengujian pada smartphone Sony Experia P 


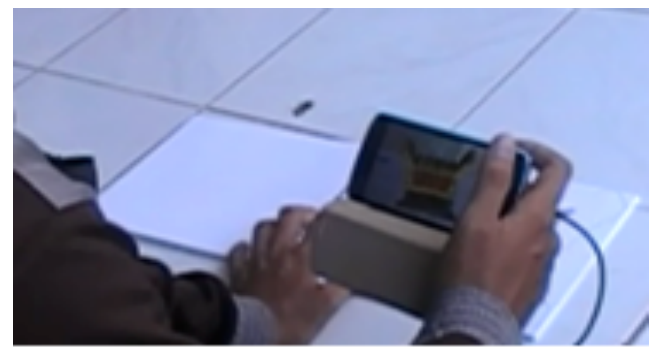

Gambar 11. Pengujian pada smartphone LG Nexus 4

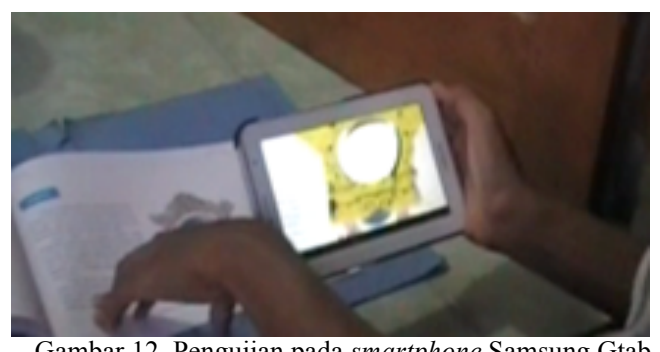

Gambar 12. Pengujian pada smartphone Samsung Gtab P3100

Pada pengujian penggunaan aplikasi pada beberapa hardware yang berbeda hampir semua menghasilkan keluaran (output) yang memuaskan, semua proses pada aplikasi dapat ditampilkan dengan baik, kesan penguji terhadap aplikasi sangat baik. Namun terdapat hardware yang kurang mampu untuk menjalankan aplikasi Augmented Reality Bookpengenalan perangkat gamelan Bali dengan baikyaitu pada smartphone Samsung Gtab P3100 dan Sony Experia P.Saat aplikasi sudah berjalan dan berhasilmenampilkan beberapa objek, ketika ingin mampilkan objek lainnya terjadi error dan aplikasi keluar tanpa kehendak penguji, karena hardwaresmartphonetersebut tidak mampu untuk melakukan render objek 3D yang rumit dan berkapasitas besar.

\section{SIMPULAN}

Berdasarkan hasil analisis, implementasi dan pengujian dapat ditarik kesimpulan sebagai berikut.

1. Library Vuforia yang merupakan libraryAugmented Reality menggunakan aplikasi Unity mampu menciptakan aplikasi
Augmented Reality Bookpengenalan perangkat gamelan Baliyang mampu melakukan pelacakan penanda sehingga dapat menampilkan objek 3 dimensi gamelan Bali dan suara narasi penjelasan serta suara yang dapat dihasilkandari perangkat gamelanyang ditampilkan.

2. Berdasarkan hasil pengujian mengindikasikan bahwa terdapat beberapa faktor yang mempengaruhi aplikasi Augmented Reality Bookpengenalan perangkat gamelan Balimampu berjalan dengan baik yaitu faktor keadaan lingkungan saat aplikasi dijalankan (pencahayaan dan jarak smartphone ke penanda) dan faktor kemampuan hardware smartphone yang digunakan untuk menjalankan aplikasi.

3. Aplikasi Augmented Reality Bookpengenalan perangkat gamelan Bali dapat digunakan sebagai sarana guna menarik minat pembaca khususnya remaja untuk mempelajari, memperkenalkan dan melestarikan perangkat gamelan Bali yang tentunya turut melestarikan budaya bangsa.

\section{REFERENSI}

[1] Muhammad, Dijibril. 2012. 14 Maret. "Gamelan Bali sejajar dengan Seni Musik Barat". Republika Online. http://www.republika.co.id/berita/senggang/senibudaya/12/03/14/m0uk29-gamelan-bali-sejajar-denganseni-musik-barat (diakses tanggal 8 Desember 2012)

[2] ISI, Denpasar. 2011. "Dampak Teknologi terhadap minat berkesenian anak muda di Br. Mas Bedulu". http://isidps.ac.id/blog/dampak-teknologi-terhadap-minatberkesenian-anak-muda-di-br-mas-bedulu (diakses tanggal 27 November 2012)

[3] Andriyadi, Anggi. 2011. Augmented Reality With ARToolkit Reality Leaves a lot to Imagine. Lampung : Augmented Reality Team.

[4] Aryasa B.A., I W. M. 1977. Perkembangan Seni Karawitan Bali. Denpasar : Proyek Sasana Budaya Bali.

[5] Rembang, I Nyoman. 1985. Hasil Pendokumentasian Notasi Gending-Gending Lelambatan Klasik Pegongan Daerah Bali. Denpasar : Departemen Pendidikan dan Kebudayaan, Direktorat Jendral Kebudayaan, Proyek pengembangan Kesenian Bali. 